Portland State University

PDXScholar

Environmental Science and Management

Faculty Publications and Presentations

7-2017

\title{
Bending the Carbon Curve: Fire Management for Carbon Resilience under Climate Change
}

\author{
E. Louise Loudermilk \\ USDA Forest Service \\ Robert M. Scheller \\ Portland State University, rmschell@pdx.edu \\ Peter J. Weisberg \\ University of Nevada, Reno \\ Alec M. Kretchun \\ Portland State University
}

Follow this and additional works at: https://pdxscholar.library.pdx.edu/esm_fac

Part of the Environmental Indicators and Impact Assessment Commons, Environmental Studies

Commons, and the Natural Resources Management and Policy Commons

Let us know how access to this document benefits you.

\section{Citation Details}

Loudermilk, E. L., Scheller, R. M., Weisberg, P. J., \& Kretchun, A. (2017). Bending the carbon curve: fire management for carbon resilience under climate change. Landscape Ecology, 32(7), 1461-1472.

This Article is brought to you for free and open access. It has been accepted for inclusion in Environmental Science and Management Faculty Publications and Presentations by an authorized administrator of PDXScholar. Please contact us if we can make this document more accessible: pdxscholar@pdx.edu. 


\title{
Bending the carbon curve: fire management for carbon resilience under climate change
}

\author{
E. L. Loudermilk • R. M. Scheller • P. J. Weisberg $\cdot$ Alec Kretchun
}

Received: 18 January 2016/ Accepted: 26 September 2016/Published online: 4 October 2016

(C) Springer Science+Business Media Dordrecht (outside the USA) 2016

\begin{abstract}
Context Forest landscapes are increasingly managed for fire resilience, particularly in the western US which has recently experienced drought and widespread, high-severity wildfires. Fuel reduction treatments have been effective where fires coincide with treated areas. Fuel treatments also have the potential to reduce drought-mortality if tree density is uncharacteristically high, and to increase long-term carbon storage by reducing high-severity fire probability.

Objective Assess whether fuel treatments reduce fire intensity and spread and increase carbon storage under climate change.

Methods We used a simulation modeling approach that couples a landscape model of forest disturbance and succession with an ecosystem model of carbon dynamics (Century), to quantify the interacting effects
\end{abstract}

\section{E. L. Loudermilk (ه)}

Forestry Sciences Laboratory, Center for Forest Disturbance Science, USDA Forest Service, 320 Green Street, Athens, GA 30602, USA

e-mail: elloudermilk@fs.fed.us

R. M. Scheller · A. Kretchun

Department of Environmental Science and Management, Portland State University, P.O. Box 751, Portland, OR, USA

\section{P. J. Weisberg}

Department of Natural Resources and Environmental Science, University of Nevada, Reno, 1664 N. Virginia St., Mail Stop 186, Reno, Nevada 89557, USA of climate change, fuel treatments and wildfire for carbon storage potential in a mixed-conifer forest in the western USA.

Results Our results suggest that fuel treatments have the potential to 'bend the $\mathrm{C}$ curve', maintaining carbon resilience despite climate change and climate-related changes to the fire regime. Simulated fuel treatments resulted in reduced fire spread and severity. There was partial compensation of $\mathrm{C}$ lost during fuel treatments with increased growth of residual stock due to greater available soil water, as well as a shift in species composition to more drought- and fire-tolerant Pinus jeffreyi at the expense of shade-tolerant, fire-susceptible Abies concolor.

Conclusions Forest resilience to global change can be achieved through management that reduces drought stress and supports the establishment and dominance of tree species that are more fire- and droughtresistant, however, achieving a net $\mathrm{C}$ gain from fuel treatments may take decades.

Keywords Carbon - Wildfire $\cdot$ Climate change $\cdot$ Fuel treatments $\cdot$ Resilience $\cdot$ Lake Tahoe Basin . Simulation modeling

\section{Introduction}

Climate change is an ongoing and evolving threat to forest health, particularly in water-limited regions of 
the western U.S., and ultimately threatens the carbon storage capacity of these forests (Bachelet et al. 2001; Lenihan et al. 2003; Law et al. 2004; Goward et al. 2008). The most dramatic and immediate impacts of climate change may be realized through the alteration of natural disturbance regimes. Disturbance types that have acted as primary catalysts of community change and $\mathrm{C}$ release in the climate change context include wildfire (Scholze et al. 2006; Westerling et al. 2006; Littell et al. 2009), insect outbreaks (Kurz et al. 2008; Bentz et al. 2010; Bright et al. 2012; Hicke et al. 2012); tree disease (van Mantgem et al. 2009) and land use change (Hansen et al. 2001; Radeloff et al. 2005). The inevitability of altered disturbance regimes and uncharacteristic environmental change necessitates careful consideration of management interventions to promote long-term forest health.

Fuel treatments (e.g., thinning of small diameter trees and potential 'ladder' fuels that allow fire to carry into the canopy, coupled with prescribed fire) can reduce wildfire size and severity where treatments and wildfire intersect (Safford et al. 2009, 2012; Syphard et al. 2011; Campbell et al. 2012; Loudermilk et al. 2014b). Fuel treatments can also reduce landscapescale $\mathrm{C}$ emissions over many decades if they are designed to have a high probability of spatially overlapping with wildfire (Schmidt et al. 2008) and do not excessively reduce living biomass (Hurteau et al. 2008; Hurteau and North 2009; Loudermilk et al. 2014b). If, however, fire is uncommon or infrequent, fuel treatments are unlikely to reduce $\mathrm{C}$ emissions (Mitchell et al. 2009; Campbell and Ager 2013; Restaino and Peterson 2013). Campbell et al. (2012) concluded that there was low likelihood that fuel treatments would increase terrestrial $\mathrm{C}$ stocks in western US forests because short-term $\mathrm{C}$ losses were unlikely to be offset by reduced emissions during wildfire, mainly due to a perception of low probability that a given forest stand would burn in a high-severity fire within a relevant timeframe. However, climate change may increase the probability of a wildfire intersecting a fuel treatment, especially in areas with high ignition potential (i.e., near the Wildland Urban Interface [WUI], campgrounds) (Syphard et al. 2011; Yang et al. 2015), and where wildfires are physically constrained by geographic barriers and treatments are intensively implemented (e.g., Loudermilk et al. 2014a, b). Fuel treatments may also be important for reducing competition for soil water where it is limiting, increasing drought hardiness and productivity of the remaining canopy trees (Kolb et al. 2007; Anning and McCarthy 2013). Fuel treatment efficacy has not, however, been examined for landscape-scale forest $\mathrm{C}$, including living, detrital, and soil organic $\mathrm{C}$ (SOC), in a climate change context. Fuel treatment effects on carbon balance are not inherently obvious because short-term $\mathrm{C}$ removals associated with treatments must be balanced against long-term effects on reducing frequency or severity of wildfire (Loudermilk et al. 2014b; Kent et al. 2015). This requires simulation modeling approaches to integrate $\mathrm{C}$ dynamics across multiple disturbance events that define climate-related shifts in fire regime. For example, Laflower et al. (2016) simulated fuel treatment effects on $\mathrm{C}$ in western Washington, USA, and found that thinning did not increase landscape $\mathrm{C}$ although residual growth rates were increased.

Previous research in our study area, the Lake Tahoe Basin (LTB), CA and NV, USA, indicated that wildfire activity was the main determinant in altering $\mathrm{C}$ sequestration potential in all above and belowground C pools. Higher emission scenarios had larger effects (Loudermilk et al. 2013), due to reduced fine fuel moisture and higher fire ignition and spread potential for extended periods. Simulated SOC pools had the smallest sensitivity to climate change due to time-lags in humification and changes in heterotrophic respiration. Regardless of the effects from climate change and associated wildfires, the basin remained a $\mathrm{C}$ sink [positive net ecosystem carbon balance (NECB)] in all simulations, and continued to sequester $\mathrm{C}$ because of the landscape legacy of a large logging event in the 19th century (Loudermilk et al. 2013). Fuel treatments applied on a 15 year rotation period across $\sim 60 \%$ of the LTB were successful at reducing wildfire activity, where treatment placement in high ignition potential areas was critical to effectiveness (Loudermilk et al. 2014). This paper augments the earlier simulation modeling studies by incorporating effects of climate change on wildfires and drought stress and by improving existing projections of how treatments can reduce carbon loss by reducing fire severity.

Our objective was to estimate the degree to which fuel treatments produce higher $\mathrm{C}$ stocks relative to untreated forests ('bending the $\mathrm{C}$ curve') under projected climate change and wildfire scenarios (Fig. 1). We quantified the onset of fuel treatment $C$ 


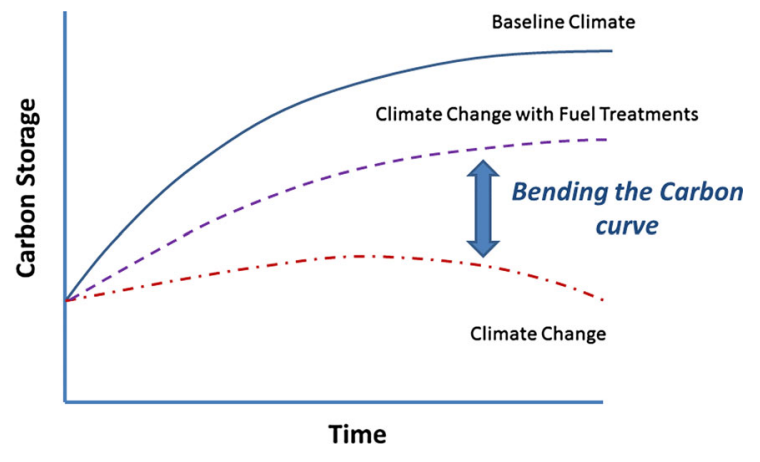

Fig. 1 Conceptual diagram of landscape Carbon dynamic under baseline (i.e., contemporary, typically based on the last 30 years) climate, under climate change, and under climate change with fuel treatments

effectiveness as the earliest year of net $\mathrm{C}$ gain, when $\mathrm{C}$ from simulations with fuel treatments exceeded $\mathrm{C}$ from simulations without fuel treatments. We further considered the goal of managing forests for 'landscape carbon resilience', which we define as the potential to sequester $\mathrm{C}$ despite changing climate and altered disturbance regimes. We used a simulation modeling approach that included the effects of climate change and wildfire size and severity. We simulated both climate change (moderate and high emissions scenarios) and fuel treatments across the LTB. We conducted a comprehensive assessment of forest $\mathrm{C}$, including living, detrital and SOC. We assessed the effects of simulated fuel treatments on carbon storage potential across climate scenarios. We also examined the potential effects of fuel treatments on soil water available for tree growth.

\section{Methods}

Study area

Our study area comprises ca. 85,000 ha of forested land in the Lake Tahoe Basin (LTB, Fig. 2). The climate is Mediterranean with a summer drought period. The basin-like topography and elevation range (ca. 1897-3320 m) control local temperature and precipitation patterns. Current mean daily temperatures range from 6 to $24{ }^{\circ} \mathrm{C}$ and have an annual average temperature of $5{ }^{\circ} \mathrm{C}$. Snowfall is the primary form of precipitation (50-150 cm annually), which occurs mainly between October and May, and

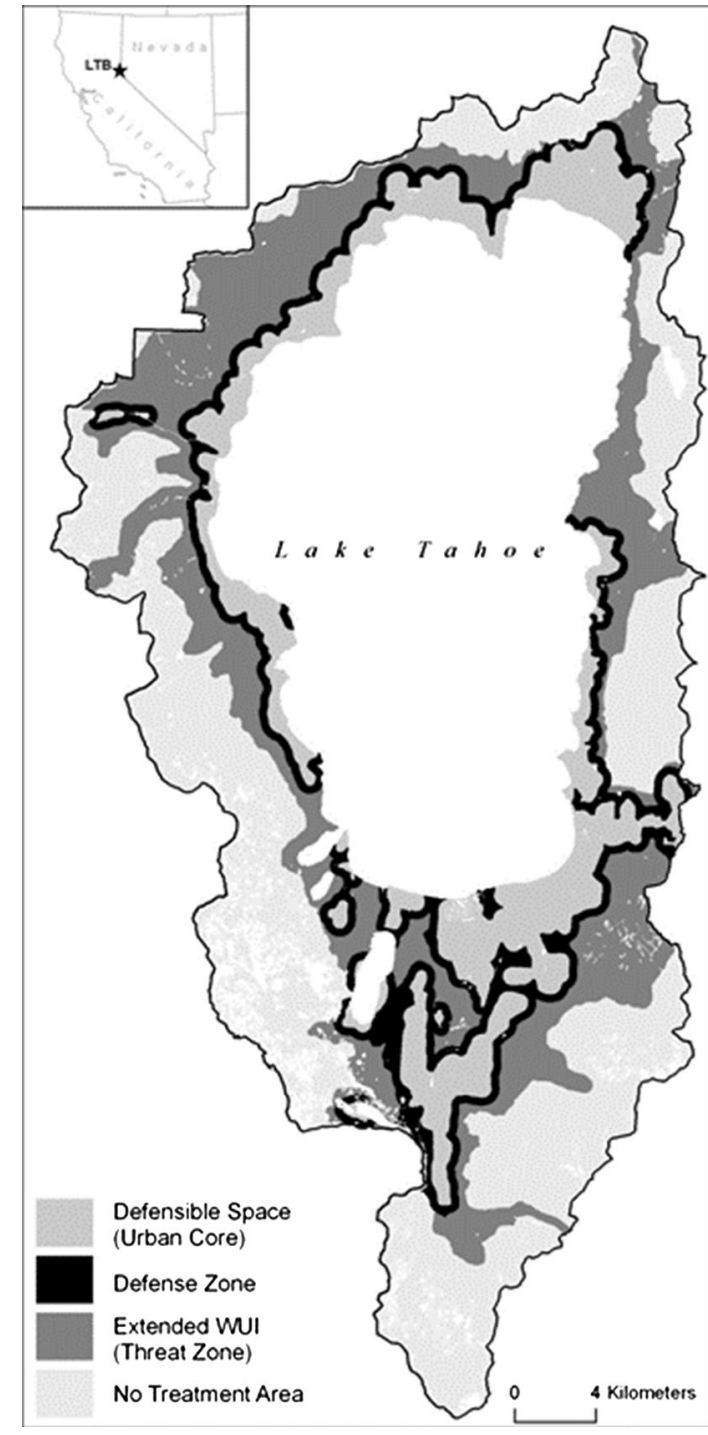

Fig. 2 Study area, the forested region of the Lake Tahoe Basin, $\mathrm{CA}$ and NV, USA. The fuels management areas are concentrated around the lake shore in three distinct regions, namely, the defensible space, the defense zone, and the extended wildland urban interface (WUI). Details are in Loudermilk et al. (2014)

snowpack persists into the summer at higher elevations. Soils are classified as shallow Entisols or Inceptisols and the more developed soils are Alfisols; the substrate is mainly granite with ancient volcanic bedrock lining the north shore (Rogers 1974).

The forests of the LTB are generally mixed western conifer, dominated by Jeffrey pine (Pinus jeffreyi) and dry mixed-conifer, with lesser area of upper montane, subalpine, montane shrublands, and riparian areas. Tree species and shrub functional groups are listed in 
Table 1 and detailed in Loudermilk et al. (2013, 2014).

\section{Simulation modeling}

We used the LANDIS-II landscape change simulation model to estimate the effects of climate change and fuel treatments on living, detrital and SOC (Fig. 3). We have previously calibrated and validated the model for LTB forests (Loudermilk et al. 2013, 2014; Kretchun et al. 2016). We summarize our approach in brief here.

Forest succession and $\mathrm{C}$ dynamics were simulated using the Century Succession extension ('Century') for the LANDIS-II model (Scheller et al. 2011). In Century, the age and spatial distributions of dominant tree and shrub species are determined by disturbance, dispersal, and establishment, both dependent upon life history attributes (Table 1). Tree and shrub species vary in their response to disturbance; disturbances cause mortality and increase the light available for establishment, dependent on the shade tolerance of each species.

Trees and shrubs are represented as cohorts with a defined age range; each has associated biomass: aboveground wood and leaf/needles, coarse roots, and fine roots (collectively output as 'live C'). Within each 1 ha grid cell, cohorts compete for growing space (a proxy for available light), nitrogen, water, and also vary in terms of establishment ability in varying climatic conditions. Monthly soil moisture within each cell is determined by inputs (via rain or melting snow) minus evapotranspiration (Parton et al. 1994). Subsequently aboveground net primary productivity is reduced by a soil moisture limiting factor (Parton et al. 1994) that has previously been tested and calibrated against tree-ring data (Loudermilk et al. 2014a; Kretchun et al. 2016). In summary:

$$
\frac{d \text { Live }_{i j}}{d t}=f(\text { Age, Competition, Disturbance, } A N P P)
$$

where $i j$ represents cohort $i$ within cell $j$.

In Century, detrital and soil organic C (SOC, collectively 'dead C') dynamics follow the behaviors as found in the CENTURY model (Parton et al. 1983, 1994). In summary:

\section{$\frac{d \text { Dead }_{i j}}{d t}=f($ Disturbance, Soil Moisture, \\ Temperature, Available Nitrogen)}

where $i j$ represents dead $\mathrm{C}$ pool $i$ within cell $j$.

Initial forest conditions were created from the maps and species data developed by the FCCS, coupled with FIA data, and recent wildfire activity (details in Loudermilk et al. 2013). Within each 1 ha grid cell, all C pools (live, detrital, SOC) are simulated at a monthly time step, based on $\mathrm{C}$ pools from the previous time step plus cohort growth based on the mean monthly climate for that year and minus $\mathrm{C}$ lost to fire or fuel treatments (below). We report landscape-scale $\mathrm{C}$ density $\left(\mathrm{g} \mathrm{C} \mathrm{m}^{-2}\right)$ over time or NECB. Landscape heterogeneity is generated by initial plant and soil conditions, spatial distribution and frequency of disturbance, species response to disturbance, climate, and soil conditions, and recruitment patterns.

Wildfire dynamics are determined by fuel type, fire weather, ignitions, and topography (Sturtevant et al. 2009) and simulated in the Dynamic Fire and Fuels Systems extension ('DFFS'). Fuel conditions and fire weather are climate dependent, affecting in particular, fine-fuel moisture and fuel availability. Wildfire activity and severity respond to changes in seasonal distributions of fire weather, derived from current and future climate data (Loudermilk et al. 2013) and projected fire ignitions (Yang et al. 2015). Climate therefore influences both rate of spread and fire severity. Three fire regions were created and within each, the wildfire regime was calibrated to recent (1995-2007) fire data, including fire suppression, and suppression was assumed to persist into the future. Following calibration, simulated fire sizes become an emergent model behavior and respond to future seasonal fire weather and fuel conditions through fine fuel moisture and fuel availability (Sturtevant et al. 2009). Simulated fire rotation period decreased from 360 to 293 years under the 'high emissions' climate regime (see 'Scenarios' below) as compared to current climate (Loudermilk et al. 2013). When a cell is burned, live $\mathrm{C}$ is volatilized at a rate dependent upon fire severity and mortality (a function of age and fire tolerance, Table 1) following Karam et al. (2013). Detrital C is volatilized at a rate dependent upon fire severity; SOC is unaffected by fire. 


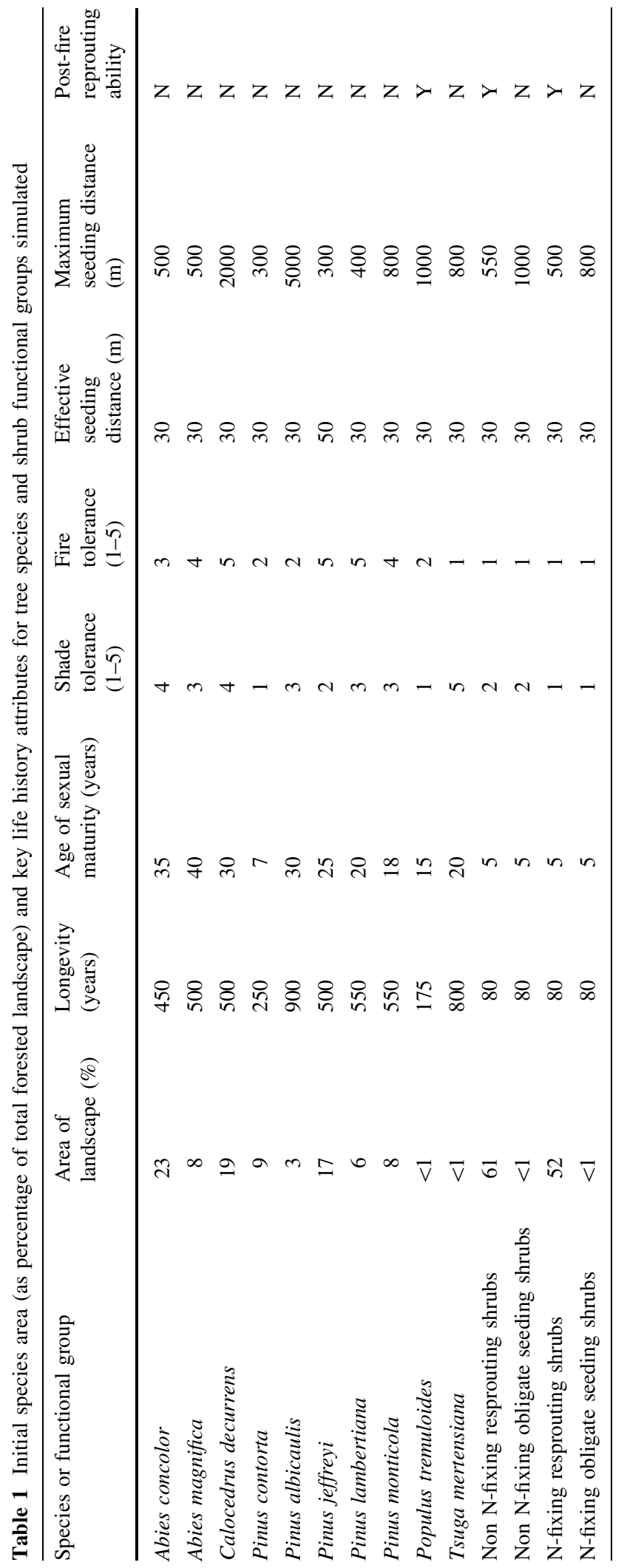




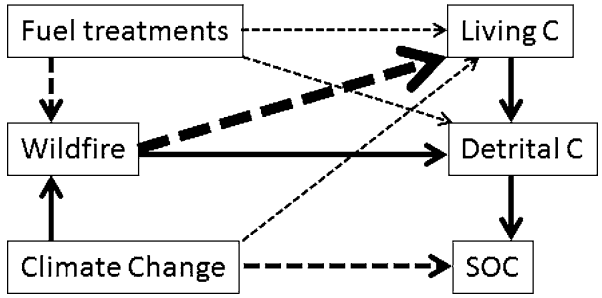

Fig. 3 Conceptual diagram of the primary effects of fuel treatments (forest thinning and prescribed fire) and climate change on the three primary landscape $\mathrm{C}$ pools. Solid lines indicate positive effects, dashed lines negative effects, and line thickness indicates expected strength of the effect. Fuel treatments and wildlife have negligible direct effects on SOC; climate change has a negligible effect on detrital C. Fuel treatments reduce wildfire, living $\mathrm{C}$, and detrital $\mathrm{C}$. Wildfire reduces living $\mathrm{C}$, but increases detrital $\mathrm{C}$. Climate change increases wildfire and reduces living $\mathrm{C}$ (via drought) and SOC (via increased heterotrophic respiration). Because fuel treatments reduce wildfire, mortality of living $\mathrm{C}$ is substantially reduced. Differences in location and frequency of each disturbance, species response to disturbance, changing climate, and soil conditions, and overall recruitment patterns alter the spatial heterogeneity of these $\mathrm{C}$ pools across the landscape

Fuel treatments were simulated as a 'thinning from below' prescription whereby small or younger conifers are removed, preferentially targeting more shadetolerant, fire sensitive species, e.g., white fir, and fine fuels are reduced via mastication or prescribed burning (Loudermilk et al. 2014). Following treatment, treated stands are assigned a new fuel type with higher crown-to-base height and reduced canopy bulk density; treatments were effective for 10-15 years, dependent on prescription type, after which they are reclassified to a fuel type assuming no treatment. Fuel treatments were implemented following a plan that reflects contemporary forest management goals: 15 year initial implementation stage of intensive treatments in approximately $60 \%(\sim 40,000 \mathrm{ha})$ of the forested area (Fig. 2), followed by 85 years of maintenance treatments. Stands were chosen for treatment based on their classified fuel types, where they were treated in order of fire hazard to achieve a 15 year rotation interval (Loudermilk et al. 2014b). Fuel treatments reduce live $\mathrm{C}$ and reduce the probability and severity of fire in any given grid cell (Fig. 3). Treatment scenarios and prescriptions, including efficacy length, were estimated from expert knowledge during scientist-manager workshops, described in (Loudermilk et al. 2012, 2014b).
We ran simulations using three climate scenarios: historic (PRISM data, 1960-1990), moderate (B1), and high (A2) emissions scenarios (see below), with and without fuel treatments, from 2010 to 2110 . Wildfires were simulated in all scenarios, and responded to climate driven changes in fire weather, changing ignitions, and fuel conditions as well as changes in fuel type as determined by fuel treatment prescriptions.

Due to the availability of down-scaled data and computational limits, we chose two climate projections to bracket the potential range of climate changes, e.g., (Scheller and Mladenoff 2005; Koca et al. 2006; Duveneck et al. 2014). We used downscaled Geophysical Fluid Dynamics Laboratory (GFDL) general circulation models of high (A2) and moderate (B1) global $\mathrm{CO}_{2}$ emissions scenarios. The downscaling was processed using PRISM data [Parameter-elevation Regressions on Independent Slopes Model, http:// www.prism.oregonstate.edu/, PRISM 30-year Normals (1971-2000), $800 \mathrm{~m}^{2}$ ] to provide area-weighted averages across each ecoregion (5) and fire region (3), within which we assumed a homogeneous climate. The daily data (temperature, precipitation) were averaged to five year monthly means with variation, which is used for input into Century. For the historic, $\mathrm{B} 1$, and $\mathrm{A} 2$ emissions scenarios, the mean annual temperature at year 2110 was $5.2,7.3$, and $9.3{ }^{\circ} \mathrm{C}$, respectively. There were no differences in precipitation for B1 and A2, but both were about $22 \%$ less than the historic scenario at year 2110 ( mean 95 vs. $115 \mathrm{~cm}$ total annual precipitation, respectively). The daily data were also used to generate fire weather (including fuel moisture and wind speeds), also binned into 5 year periods for the simulation of wildfire in the DFFS (also see Loudermilk et al. 2013). For consistency, the first 5-year interval of B1 climate data was used to represent a continuation of the current climate (base climate).

In addition to the full landscape simulations, we also estimated the effect of fuel treatments on soil water available for growth. We conducted four single cell (1 ha homogeneous area) simulations to test this effect; because soil moisture varies at a monthly time scale and by cohort, the information could not be output at the landscape scale due to memory limitations. We simulated forest growth at two treatment levels: (1) maximum aboveground biomass, and (2) $50 \%$ biomass, mimicking the effects of fuel 

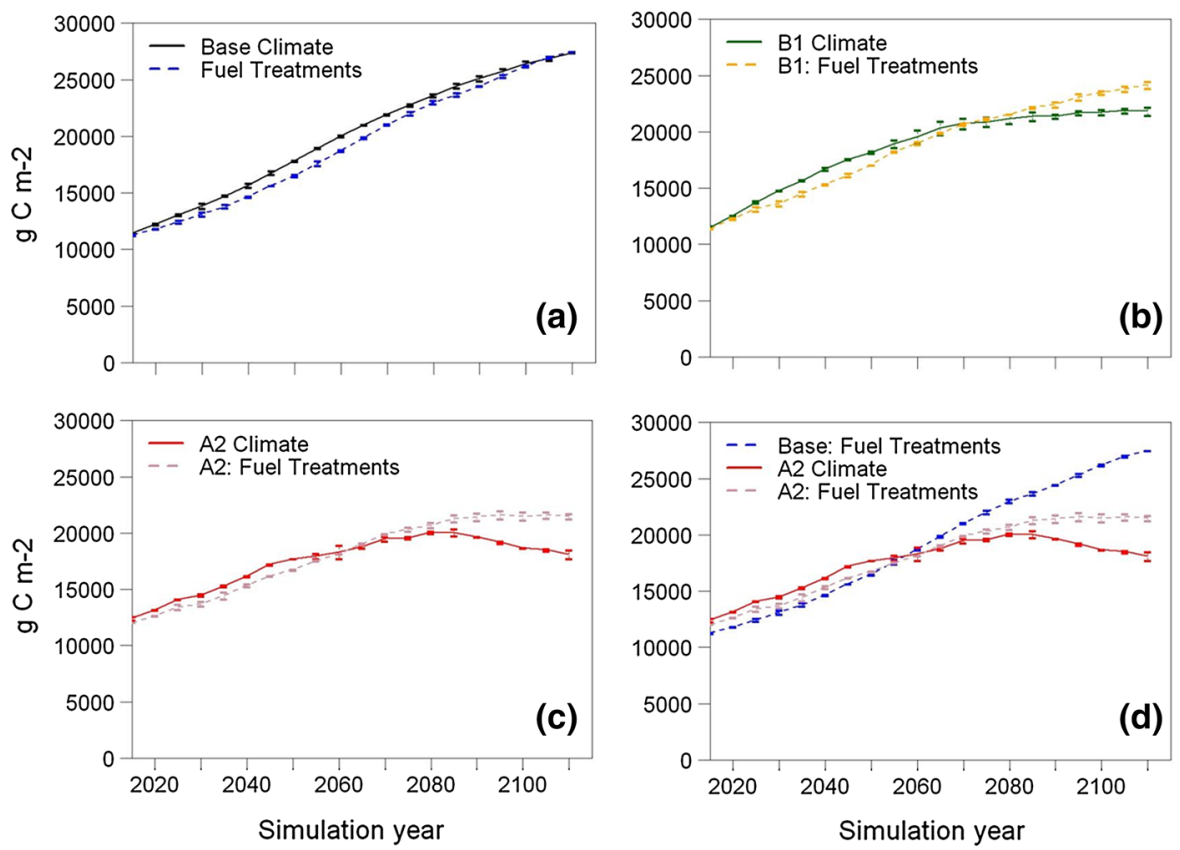

Fig. 4 Fuel treatment effects on landscape $\mathrm{C}$ in a changing climate, simulated in the Lake Tahoe Basin, CA and NV. Graphs are represented as mean C density of all C pools simulated [Live $\mathrm{C}+$ detrital $\mathrm{C}$ (included dead and downed wood and litter) + SOC]. a Baseline climate based on PRISM 30-year Normals (1971-2000), with and without fuel

treatments on available soil moisture. These two treatment levels were applied to two different communities: (1) one community consisting of mixed Jeffrey pine and white fir (Abies concolor), the most abundant community type and the most frequently thinned at the LTB, and (2) a community with only Jeffrey pine, representing the typical condition postfuel treatment. These single cells were run for 20 years, under historic climate to estimate fuel treatment effects on soil moisture and the growth of residual cohorts.

\section{Results}

When wildfire intersected fuel treatments, fire severity was reduced and less $\mathrm{C}$ was volatilized; total $\mathrm{C}$ initially declined and later increased, surpassing control (no fuel treatment) $\mathrm{C}$ and produced a higher NECB. In addition, the removal of fire-sensitive young white fir cohorts (that serve as ladder fuels) reduced crowning potential. The remaining canopy, typically

treatments. b Moderate emissions (B1) (Mastrandrea et al. 2011) from Geophysical Fluid Dynamics Laboratory (GFDL) general circulation models, with and without fuel treatments. c High emissions (A2) from GFDL, with and without fuel treatments. d High and baseline scenarios compared, with and without fuel treatments

Jeffrey pine, was more fire tolerant and over repeated treatments, the replacement of white fir with Jeffrey pine reduced $\mathrm{C}$ loss due to wildfire (Loudermilk et al. 2014).

Under a warmer climate, the onset of fuel treatment $\mathrm{C}$ effectiveness (quantified as the simulation year when total C (live, detrital, SOC, $\mathrm{g} \mathrm{C} \mathrm{m}^{-2}$ ) with fuel treatments exceeded $\mathrm{C}$ without fuel treatments) occurred earlier than simulations assuming a contemporary climate (Fig. 4). Fuel treatment $\mathrm{C}$ effectiveness under a contemporary climate, moderate emissions climate, and high emissions climate occurred in year 2105, 2070, and 2060, respectively. The projected timing of fire shifted to earlier in the calendar year due to increased fire spread and ignition potential (Yang et al. 2015) — particularly near treatment areas-under warmer climates and therefore an increased probability of wildfires intersecting fuel treatments, similar to Syphard et al. (2011). Mean annual area burned was reduced by half, more than doubling the fire rotation period, for all three climate scenarios when treatments were simulated. 
Simulated fuel treatments reduced water stressthe effect of soil water availability on net primary productivity, although the differences were not large (Table 2). Therefore, although $\mathrm{C}$ is lost during fuel treatments, this is compensated in small part with increased potential growth of the remaining cohorts. This effect was magnified when the less drought intolerant white fir was absent, as would be expected post-treatment or under a warmer climate, when white fir regeneration is reduced (Loudermilk et al. 2014) (Table 2).

\section{Discussion}

Our simulations suggest that fuel treatments have the potential to 'bend the $\mathrm{C}$ curve' through the combined effects of reduced fire spread and severity and partial compensation of $\mathrm{C}$ lost during fuel treatments and, to a lesser extent, with increased growth of residual stock due to greater available soil water. This fire and drought resiliency was mainly due to changes in species composition-drought and fire tolerant Jeffrey pine favored over white fir (see Loudermilk et al. 2013 and Table S8 within) - and forest structure, and the efficacy of fuel treatments on reducing fire hazard. The effects on soil water availability were minor as was a reduction of soil heterotrophic respiration (Loudermilk et al. 2013). Thus, creating a more fire and drought tolerant landscape through the use of fuel treatments may create a landscape with higher $\mathrm{C}$ resilience to climate change, most notably in ecoregions where climate change forecasts indicate a transition to increased water limitation.

As climate change creates more favorable conditions for more wildfire activity (i.e., longer and more frequent drought), fuel treatments may become more effective. At the same implementation rate (15 year rotation period), fire overlap with treated stands increased for simulated climate change scenarios relative to contemporary climate conditions. As treatments were targeted in areas where ignitions were most likely to occur [near urban core (Loudermilk et al. 2014b)], their effectiveness had landscape implications for reducing $\mathrm{C}$ emissions from wildfires in the long run. Fuel treatment $\mathrm{C}$ effectiveness occurred 30-40 years earlier in climate change scenarios than the contemporary climate scenario (Fig. 4). This contrasts with previous research (Mitchell et al. 2009; Campbell et al. 2012) which found no C benefits of fuel treatments in mature ponderosa pine forests of eastern Oregon.

However, our estimated payoffs for $\mathrm{C}$ management (achieving net $\mathrm{C}$ gain from fuel treatments) would likely not accrue for many (5-6) decades, requiring patient investment in fuel treatments. Fortunately, there are short term (1-2 decades) payoffs that are important for the LTB human and forest community. Fuel treatments will immediately reduce hazardous fuels around nearby WUI. With the change in understory light conditions, treatments will promote establishment of more shade sensitive, yet more fire tolerant species, such as Jeffrey pine and sugar pine $(P$. lambertiana) (Hurteau and North 2009; Loudermilk et al. 2014b). In the short and long term, the payoff will be maintenance of wildfire and drought tolerant conditions, while creating structural and biological heterogeneity that promotes long-term resistance to wildfires, disease, and insects (Reinhardt et al. 2008; Hurteau and North 2009). However, it is important that thinning treatments be implemented with the goal of maintaining or restoring structural heterogeneity of forests, and that silvicultural practices emphasizing uniform spacing of trees be avoided (North et al.

Table 2 The simulated effect of biomass reduction and species composition on soil water limitations to net primary productivity (NPP; $\mathrm{g} \mathrm{C} \mathrm{m}^{-2}$ year $^{-1}$ )

\begin{tabular}{lll}
\hline Relative aboveground biomass & \multicolumn{2}{l}{ Community composition } \\
\cline { 2 - 3 } & Jeffrey pine and white fir & Jeffrey pine only \\
\hline $100 \%$ (representing no fuel treatments) & 0.388 & 0.478 \\
$50 \%$ (representing heavy thinning) & 0.422 & 0.512 \\
\hline
\end{tabular}

Growth limitations (ranging from 0.0: no growth-to 1.0: no limit to growth) are applied to monthly maximum NPP within the Century Succession extension and reduce growth proportionally; growth limitations were averaged across all cohorts on site and over 20 years 
2009). In our simulations, the most pronounced influence from treatments was the change in species composition and structure within managed areas (Loudermilk et al. 2014a, b). This compensatory response dampened the overall effects on changes in forest $\mathrm{C}$ (tree removal vs. new establishment and growth). Furthermore, creating a more fire resilient landscape may create a more climate resilient one, by reducing drought stress and drought related fire activity as well as supporting the establishment of more fire tolerant species across the landscape (Agee and Skinner 2005; Reinhardt et al. 2008; Loudermilk et al. 2014b). Although there may be more direct physiological effects from climate change on individual species (e.g., Dolanc et al. 2013), the future climate-fire dynamics may overshadow these effects, even with small increases in wildfire activity (Loudermilk et al. 2013; Liu and Wimberly 2016).

Although the primary goal of fuel treatments is often to reduce potential for high-intensity crown fire, and may also encompass the restoration of forest structure, the effects on water availability can be significant and should be considered in the context of climate change adaptation. We found a moderate increase in simulated water availability due to fuel treatments, illustrating how fuel treatments may reduce drought-induced mortality and/or growth reduction. This is in contrast to another forest landscape modeling study using the LandClim model that found only a short-term effect of thinning ( $<20$ years) on water availability (Elkin et al. 2015). Following this reduction of negative drought effects on forest health, the effect of thinning was swamped by the large magnitude of climate change responses, or even helped to facilitate a compositional shift to more drought-tolerant species. Our model did not, however account for mortality from drought or the enhanced susceptibility of drought stressed trees to insect attack (Bentz et al. 2010), or other causes of mortality, e.g., windthrow, that can change landscape fuel conditions (Parker et al. 2006). These drought associated feedbacks with tree physiology, fuel conditions, and wildfire activity could likely enhance the effectiveness of fuel treatments more so than what was projected here. However, fuel treatments that reduce stand density may not improve forest health in higherelevation, upper-montane forests, where denser stands in the LTB have been associated with lower mortality rates particularly during wet periods (Van Gunst et al. 2016).

The limitations to this modeling approach have been considered elsewhere (Loudermilk et al. 2013, 2014a, b; Kretchun 2016) and include parameter, model, and inherent uncertainty (Higgins et al. 2002). Our LANDIS-II simulations did not include a full carbon life-cycle analysis in the sense that emissions from harvest, transport, and subsequent utilization of removed biomass were not considered. However, such an analysis for nearby Independence Lake, in a similar forest type within $30 \mathrm{~km}$ of our study area, found that emissions from mechanical treatments and transportation of woody biomass each constituted less than $1 \%$ of total emissions (Winford and Gaither 2012). An additional caveat is that our scenarios assume that fuel treatments are effective and complete, incorporating appropriate slash disposal and management of understory vegetation (e.g., prescribed burning). This is not always applied in practice due to environmental regulations aimed at protecting air quality and the clarity of Lake Tahoe. In addition, it is worth considering whether these results are generalizable beyond the LTB. The LTB is unique in that it is a tightly bounded watershed (the surrounding peaks limit fire spread from neighboring landscapes), has a limited and tightly delineated WUI, and has extensive resources for conducting fuel treatments and suppressing wildfires. These conditions are nearly optimal for implementing fuel treatments and maintaining their effectiveness through time. After the initial round of treatments, maintenance treatments are easier to implement, particularly if using prescribed burning (North and Hurteau 2011; Stephens et al. 2012); see Loudermilk et al. (2014) for long-term management implications. Similar effects have been estimated for the Sierra Nevada (Safford et al. 2009; Syphard et al. 2011), and other regional forests (Finney et al. 2005; Schmidt et al. 2008; Stephens et al. 2009), and may be possible where the WUI is relatively concentrated and fire risk is high.

\section{Conclusions}

We conclude that forest management using fuel treatments has the ability to bend the $\mathrm{C}$ curve, especially in projected climate conditions. More so, 
long-term fire management will be critical for increasing overall $\mathrm{C}$ resilience. Carbon resilience to global change can be achieved through management that reduces drought stress and supports the establishment and dominance of tree species that are simultaneously more fire- and drought-resistant. For $\mathrm{C}$ management, achieving fuel treatments $\mathrm{C}$ effectiveness may take decades and will become realized only as future wildfires intersect treated areas. Fuel treatments have an immediate impact on forest structure and composition, reducing fire hazard, supporting fire tolerant species, etc. for at least 1-2 decades. As simulated, these positive outcomes far outweigh the intermediary loss in forest C. Furthermore, the LTB forest is likely to continue sequestering $\mathrm{C}$ into the coming century, regardless of intensity of fuel treatments or projected fire activity, providing an 'all win' synopsis for C sequestration investments.

Acknowledgments We thank the Lake Tahoe Basin agency personnel who participated in workshops and provided data and guidance throughout the project. We also thank Alison Stanton, consultant at South Lake Tahoe, CA, Jian Yang, scientist at the Chinese Academy of Sciences, Tom Dilts, spatial analyst at the Department of Natural Resources and Environmental Science, University of Nevada-Reno, and Carl Skinner, geographer at the Pacific Southwest Research Station, USDA Forest Service for their hard work and support throughout this project. Funding was provided by the Southern Nevada Public Land Management Act (Grant No. 10 DG-11272170-038), Bureau of Lands Management (P049, P086) and in part by the Strategic Environmental Research and Development Program of the Department of Defense (RC-2243). We thank the Forestry Sciences Laboratory, Southern Research Station, USDA Forest Service, Athens, GA, USA, for their support.

\section{References}

Agee JK, Skinner CN (2005) Basic principles of forest fuel reduction treatments. For Ecol Manag 211:83-96

Anning AK, McCarthy BC (2013) Competition, size and age affect tree growth response to fuel reduction treatments in mixed-oak forests of Ohio. For Ecol Manag 307:74-83

Bachelet D, Neilson RP, Lenihan JM, Drapek RJ (2001) Climate change effects on vegetation distribution and carbon budget in the United States. Ecosystems 4:164-185

Bentz BJ, Régnière J, Fettig CJ, Hansen EM, Hayes JL, Hicke JA, Kelsey RG, Negrón JF, Seybold SJ (2010) Climate change and bark beetles of the western United States and Canada: direct and indirect effects. BioScience 60:602-613

Bright B, Hicke J, Hudak A (2012) Landscape-scale analysis of aboveground tree carbon stocks affected by mountain pine beetles in Idaho. Environ Res Lett 7:045702
Campbell JL, Ager AA (2013) Forest wildfire, fuel reduction treatments, and landscape carbon stocks: A sensitivity analysis. J Environ Manag 121:124-132

Campbell JL, Harmon ME, Mitchell SR (2012) Can fuel-reduction treatments really increase forest carbon storage in the western US by reducing future fire emissions? Front Ecol Environ 10:83-90

Dolanc CR, Thorne JH, Safford HD (2013) Widespread shifts in the demographic structure of subalpine forests in the Sierra Nevada, California, 1934 to 2007. Glob Ecol Biogeogr 22:264-276

Duveneck MJ, Scheller RM, White MA, Handler S, Ravenscroft C (2014) Climate change effects to northeastern Minnesota and Northern Lower Michigan forests: a case for preserving diversity. Ecosphere 5:23

Elkin C, Giuggiola A, Rigling A, Bugmann H (2015) Short-and long-term efficacy of forest thinning to mitigate drought impacts in mountain forests in the European Alps. Ecol Appl 25:1083-1098

Finney MA, McHugh CW, Grenfell IC (2005) Stand-and landscape-level effects of prescribed burning on two Arizona wildfires. Can J For Res 35:1714-1722

Goward SN, Masek JG, Cohen W, Moisen G, Collatz GJ, Healey S, Houghton R, Huang C, Kennedy R, Law B (2008) Forest disturbance and North American carbon flux. Eos, Trans Am Geophys Union 89:105-106

Hansen AJ, Neilson RR, Dale VH, Flather CH, Iverson LR, Currie DJ, Shafer S, Cook R, Bartlein PJ (2001) Global change in forests: responses of species, communities, and biomes. BioScience 51:765-779

Hicke JA, Allen CD, Desai AR, Dietze MC, Hall RJ, Kashian DM, Moore D, Raffa KF, Sturrock RN, Vogelmann J (2012) Effects of biotic disturbances on forest carbon cycling in the United States and Canada. Glob Change Biol 18:7-34

Higgins PAT, Mastrandrea MD, Schneider SH (2002) Dynamics of climate and ecosystem coupling: abrupt changes and multiple equilibria. Philos Trans R Soc Lond Ser B 357:647-655

Hurteau M, North M (2009) Fuel treatment effects on tree-based forest carbon storage and emissions under modeled wildfire scenarios. Front Ecol Environ 7:409-414

Hurteau MD, Koch GW, Hungate BA (2008) Carbon protection and fire risk reduction: toward a full accounting of forest carbon offsets. Front Ecol Environ 6:493-498

Karam SL, Weisberg PJ, Scheller RM, Johnson DW, Miller WW (2013) Development and evaluation of a nutrient cycling extension for the LANDIS-II landscape simulation model. Ecol Model 250:45-57

Kent LLY, Shive KL, Strom BA, Sieg CH, Hunter ME, StevensRumann CS, Fulé PZ (2015) Interactions of fuel treatments, wildfire severity, and carbon dynamics in dry conifer forests. For Ecol Manag 349:66-72

Koca D, Smith B, Sykes MT (2006) Modelling regional climate change effects on potential natural ecosystems in Sweden. Clim Change 78:381-406

Kolb T, Agee J, Fule P, McDowell N, Pearson K, Sala A, Waring R (2007) Perpetuating old Ponderosa Pine. For Ecol Manag 249:141-157

Kretchun AM, Loudermilk EL, Scheller RM, Hurteau MD, Belmecheri S (2016) Climate and bark beetle effects on 
forest productivity-linking dendroecology with forest landscape modeling. Can J For Res 46:1026-1034

Kurz WA, Dymond CC, Stinson G, Rampley GJ, Neilson ET, Carroll AL, Ebata T, Safranyik L (2008) Mountain pine beetle and forest carbon feedback to climate change. Nature 452:987-990

Laflower DM, Hurteau MD, Koch GW, North MP, Hungate BA (2016) Climate-driven changes in forest succession and the influence of management on forest carbon dynamics in the Puget Lowlands of Washington State, USA. For Ecol Manag 362:194-204

Law BE, Turner D, Campbell J, Sun OJ, Van Tuyl S, Ritts WD, Cohen WB (2004) Disturbance and climate effects on carbon stocks and fluxes across western Oregon USA. Glob Change Biol 10:1429-1444

Lenihan JM, Drapek R, Bachelet D, Neilson RP (2003) Climate change effects on vegetation distribution, carbon, and fire in California. Ecol Appl 13:1667-1681

Littell JS, McKenzie D, Peterson DL, Westerling AL (2009) Climate and wildfire area burned in western US ecoprovinces, 1916-2003. Ecol Appl 19:1003-1021

Liu Z, Wimberly MC (2016) Direct and indirect effects of climate change on projected future fire regimes in the western United States. Sci Total Environ 542:65-75

Loudermilk EL, Kretchun AM, Scheller RM, Hurteau MD, Weisberg PJ, Skinner C, Belmecheri S (2012) Final report: drought stress and bark beetle outbreaks in the future forest: extending an existing model to inform climate change adaptation. Pacific Southwest Research Station, Tahoe Center for Environmental Studies, Incline Village

Loudermilk EL, Kretchun AM, Scheller RM, Hurteau MD, Weisberg PJ, Skinner C, Belmecheri S (2014a) Final report: drought stress and bark beetle outbreaks in the future forest: extending an existing model to inform climate change adaptation. Pacific Southwest Research Station, Tahoe Center for Environmental Studies, Incline Village

Loudermilk EL, Scheller RM, Weisberg PJ, Yang J, Dilts TE, Karam SL, Skinner C (2013) Carbon dynamics in the future forest: the importance of long-term successional legacy and climate-fire interactions. Glob Change Biol 19:3502-3515

Loudermilk EL, Stanton A, Scheller RM, Dilts TE, Weisberg PJ, Skinner C, Yang J (2014b) Effectiveness of fuel treatments for mitigating wildfire risk and sequestering forest carbon: a case study in the Lake Tahoe Basin. For Ecol Manag 323:114-125

Mastrandrea MD, Mach KJ, Plattner G-K, Edenhofer O, Stocker TF, Field CB, Ebi KL, Matschoss PR (2011) The IPCC AR5 guidance note on consistent treatment of uncertainties: a common approach across the working groups. Clim Change 108:675-691

Mitchell SR, Harmon ME, O'Connell KEB (2009) Forest fuel reduction alters fire severity and long-term carbon storage in three Pacific Northwest ecosystems. Ecol Appl 19:643-655

North MP, Hurteau MD (2011) High-severity wildfire effects on carbon stocks and emissions in fuels treated and untreated forest. For Ecol Manag 261:1115-1120

North MP, Stine P, O'Hara K, Zielinski W, Stephens S (2009) An ecosystem management strategy for Sierran mixed- conifer forests. USDA Forest Service Pacific Southwest Research Station General Technical Report PSW-GTR220

Parker TJ, Clancy KM, Mathiasen RL (2006) Interactions among fire, insects and pathogens in coniferous forests of the interior western United States and Canada. Agric For Entomol 8:167-189

Parton WJ, Anderson DW, Cole CV, Steward JWB (1983) Simulation of soil organic matter formation and mineralization in semiarid agroecosystems. In: Lowrance RR, Todd RL, Asmussen LE, Leonard RA (eds) Nutrient cycling in agricultural ecosystems. The University of Georgia, College of Agriculture Experiment Stations, Athens

Parton WJ, Ojima DS, Cole CV, Schimel DS (1994) A general model for soil organic matters dynamics: sensitivity to litter chemistry, texture and management. In: Quantitative modeling of soil forming processes: proceedings of a symposium sponsored by Divisions S-5 and S-9 of the Soil Science Society of America. Soil Science Society of America, Minneapolis, pp 147-167

Radeloff VC, Hammer RB, Stewart SI, Fried JS, Holcomb SS, McKeefry JF (2005) The wildland-urban interface in the United States. Ecol Appl 15:799-805

Reinhardt ED, Keane RE, Calkin DE, Cohen JD (2008) Objectives and considerations for wildland fuel treatment in forested ecosystems of the interior western United States. For Ecol Manag 256:1997-2006

Restaino JC, Peterson DL (2013) Wildfire and fuel treatment effects on forest carbon dynamics in the western United States. For Ecol Manag 303:46-60

Rogers JH (1974) Soil survey Tahoe Basin Area: California and Nevada. U.S. Department of Agriculture, Soil Conservation Service, Washington, DC

Safford HD, Schmidt DA, Carlson CH (2009) Effects of fuel treatments on fire severity in an area of wildland-urban interface, Angora Fire, Lake Tahoe Basin, California. For Ecol Manag 258:773-787

Safford HD, Stevens J, Merriam K, Meyer M, Latimer A (2012) Fuel treatment effectiveness in California yellow pine and mixed conifer forests. For Ecol Manag 274:17-28

Scheller RM, Hua D, Bolstad PV, Birdsey RA, Mladenoff DJ (2011) The effects of forest harvest intensity in combination with wind disturbance on carbon dynamics in Lake States mesic forests. Ecol Model 222:144-153

Scheller RM, Mladenoff DJ (2005) A spatially interactive simulation of climate change, harvesting, wind, and tree species migration and projected changes to forest composition and biomass in northern Wisconsin, USA. Glob Change Biol 11:307-321

Schmidt DA, Taylor AH, Skinner CN (2008) The influence of fuels treatment and landscape arrangement on simulated fire behavior, Southern Cascade range, California. For Ecol Manag 255:3170-3184

Scholze M, Knorr W, Arnell NW, Prentice IC (2006) A climatechange risk analysis for world ecosystems. Proc Natl Acad Sci 103:13116-13120

Stephens SL, Collins BM, Roller G (2012) Fuel treatment longevity in a Sierra Nevada mixed conifer forest. For Ecol Manag 285:204-212 
Stephens SL, Moghaddas JJ, Edminster C, Fiedler CE, Haase S, Harrington M, Keeley JE, Knapp EE, McIver JD, Metlen K (2009) Fire treatment effects on vegetation structure, fuels, and potential fire severity in western US forests. Ecol Appl 19:305-320

Sturtevant BR, Scheller RM, Miranda BR, Shinneman D (2009) Simulating dynamic and mixed-severity fire regimes: a process-based fire extension for LANDIS-II. Ecol Model 220:3380-3393

Syphard AD, Scheller RM, Ward BC, Spencer WD, Strittholt JR (2011) Simulating landscape-scale effects of fuels treatments in the Sierra Nevada, California. Int J Wildland Fire 20:364-383

Van Gunst KJ, Weisberg PJ, Yang J, Fan Y (2016) Do denser forests have greater risk of tree mortality: A remote sensing analysis of density-dependent forest mortality. For Ecol Manag 359:19-32 van Mantgem PJ, Stephenson NL, Byrne JC, Daniels LD, Franklin JF, Fule PZ, Harmon ME, Larson AJ, Smith JM, Taylor AH, Veblen TT (2009) Widespread increase of tree mortality rates in the western United States. Science 323:521-524

Westerling AL, Hidalgo HG, Cayan DR, Swetnam TW (2006) Warming and earlier spring increase western US forest wildfire activity. Science 313:940-943

Winford EM, Gaither JC (2012) Carbon outcomes from fuels treatment and bioenergy production in a Sierra Nevada forest. For Ecol Manag 282:1-9

Yang J, Weisberg PJ, Dilts TE, Loudermilk EL, Scheller RM, Stanton A, Skinner C (2015) Predicting wildfire occurrence distribution with spatial point process models and its uncertainty assessment: a case study in the Lake Tahoe Basin, USA. Int J Wildland Fire 24:380-390 